\title{
Short Communication: Effects of temperature on growth, pigment composition and protein content of an Antarctic Cyanobacterium Nostoc commune
}

\author{
RANJANA TRIPATHI, UMESH P. DHULDHAJ, SURENDRA SINGH ${ }^{*}$ \\ Centre of Advanced Study in Botany, Faculty of Science, Banaras Hindu University, Varanasi 221005, Uttar Pradesh, India. Tel: +91-542-6701101; Fax: \\ +91-542-2368174. `e-mail: surendrasingh.bhu@gmail.com
}

Manuscript received: 14 November 2012. Revision accepted: 30 November 2012.

\begin{abstract}
Tripathi R, Dhuldhaj UP, Singh S. 2012. Short Communication: Effects of temperature on growth, pigment composition and protein content of an Antarctic Cyanobacterium Nostoc commune. Nusantara Bioscience 4: 134-137. Effect of temperature variation on biomass accumulation, pigment composition and protein content were studied for the cyanobacterium Nostoc commune, isolated from Antarctica. Results confirmed the psychrotrophic behavior (optimum growth temperature $25{ }^{\circ} \mathrm{C}$ ) of the cyanobacterium. Low temperature increased the duration of lag phase and exponential growth phase. Maximum increase in biomass was recorded on $24^{\text {th }}$ day at $25^{\circ} \mathrm{C}$ and on $12^{\text {th }}$ day at $5^{\circ} \mathrm{C}$. The downshift from 25 to $5^{\circ} \mathrm{C}$ had almost negligible effect on chl $a$ content. Maximal protein content was recorded for cultures growing at $5^{\circ} \mathrm{C}$ on $12^{\text {th }}$ day. The carotenoids/chl $a$ ratio was maximum (2.48) at $5^{\circ} \mathrm{C}$ on $9^{\text {th }}$ day. It remained almost constant for cultures growing at 5 and $35^{\circ} \mathrm{C}$. There was an induction in protein synthesis following downshift in temperature from 25 to $5^{\circ} \mathrm{C}$
\end{abstract}

Key words: Cyanobacterium, low-temperature, growth rate, phycobiliproteins, pigments

\begin{abstract}
Abstrak. Tripathi R, Dhuldhaj UP, Singh S. 2012. Komunikasi singkat: Pengaruh suhu terhadap pertumbuhan, komposisi pigmen dan kandungan protein cyanobacterium dari Antartika Nostoc commune. Bioscience Nusantara 4: 134-137. Pengaruh variasi suhu terhadap akumulasi biomassa, komposisi pigmen dan kandungan protein dipelajari pada cyanobacterium Nostoc komune, yang diisolasi dari Antartika. Hasil penelitian menegaskan perilaku psikrotrofik (suhu pertumbuhan optimum $25^{\circ} \mathrm{C}$ ) dari cyanobacterium tersebut. Suhu rendah meningkatkan durasi fase lambat dan fase pertumbuhan eksponensial. Peningkatan biomassa maksimal tercatat hari ke-24 pada $25^{\circ} \mathrm{C}$ dan hari ke-12 pada $5^{\circ} \mathrm{C}$. Penurunan suhu dari $25 \mathrm{ke} 5^{\circ} \mathrm{C}$ hampir tidak berpengaruh pada kandungan chl a. Kandungan protein tertinggi tercatat pada kultur yang tumbuh pada $5{ }^{\circ} \mathrm{C}$, hari ke-12. Rasio karotenoid/chl $a$ tertinggi $(2,48)$ terjadi pada $5{ }^{\circ} \mathrm{C}$, hari ke-9. Hal ini hampir selalu konstan untuk kultur yang tumbuh pada $5-35^{\circ} \mathrm{C}$. Terdapat induksi dalam sintesis protein mengikuti penurunan suhu dari 25 ke $5{ }^{\circ} \mathrm{C}$.
\end{abstract}

Kata kunci: cyanobacterium, suhu rendah, tingkat pertumbuhan, phycobiliproteins, pigmen

Cold-stress is often lethal to living organisms. For growth to occur in low-temperature environments, cellular components such as membranes, proteins, and nucleic acids have to adapt to the cold (Cavicchioli et al. 2002). Microbial diversity of Antarctica is composed of either psychrophilic (optimum growth temperature $<15{ }^{\circ} \mathrm{C}$ ) or psychrotrophic (optimum growth temperature $>15{ }^{\circ} \mathrm{C}$ ) (Morita 1975; Veerapaneni 2009). Psychrotrophs constitute the bulk of continental Antarctica microflora. Adaptive responses of the Antarctic microbes growing in the permanently cold environments, especially at $0-4^{\circ} \mathrm{C}$ are little studied (Chattopadhyay 2006). Majority of Antarctic cyanobacteria grow in a wide range of temperature (Nadeau and Castenholz 2000; Nadeau et al. 2001). The temperature-growth response suggests their close relationship with moderate regions of the Antarctic (Seaberg 1981).

Nostoc commune (Nostocales) was collected from Schirmacher Oasis, Antarctica by Dr. Suresh Chandra
Singh, a member of the Seventeenth Indian Expedition to Antarctic (Pandey and Upreti 2000). The cyanobacterium was isolated, purified using standard microbiological techniques, and is maintained in nitrogen free BG-11medium in a culture room set at $25 \pm 1{ }^{\circ} \mathrm{C}$, illuminated with day-light fluorescent tubes having the photon fluency rate of $35 \mu \mathrm{E} \mathrm{m}^{-2} \mathrm{~s}^{-1}$ at the surface of vessels. Here, we studied the biomass accumulation (in terms of fresh weight and dry weight $\mathrm{ml}^{-1}$ volume of liquid culture harvested at 3 day intervals) and pigment composition of $N$. commune, an Antarctic cyanobacterial to different temperatures (i.e., 5, 15, $\left.25,35^{\circ} \mathrm{C}\right)$.

Growth of $N$. commune was estimated in terms of chlorophyll $a$ (chl $a$ ) content and expressed in terms of specific growth rate computed as per the method of Myers and Kratz (1955). Growth rate $(\mu)$ of $N$. commune at each temperature was estimated as changes in biomass over time from the log-linear portion of the curve using non-linear curve fit method with Boltzmann constant. Chl $a$ was 
quantified using the formula of Talling and Driver (1963), with 12.7 as extinction coefficient for chl $a$ at $663 \mathrm{~nm}$. Carotenoids were estimated according to Myers and Kratz (1955). Phycobilliproteins (PBPs) (both qualitatively and quantitatively) were analyzed by recording the absorption spectra and absorbance at various wavelengths in a UVVIS spectrophotometer (Varian, Cary100-Bio, USA) with a $1 \mathrm{~cm}$ light path. Fluorescence excitation and emission spectra were recorded in a fluorescence spectrophotometer (Hitachi F-2500, Japan). The amounts of different PBPs namely, phycocyanin (PC, $\mathrm{A}_{\max } 565 \mathrm{~nm}$ ), allophycocynain $\left(\mathrm{APC}, \mathrm{A}_{\max } 620 \mathrm{~nm}\right)$ and phycoerythrin $\left(\mathrm{PE}, \mathrm{A}_{\max } 650 \mathrm{~nm}\right)$ were determined according to the equations given by Tandeau de Marsac and Houmard (1993). Protein was estimated following the method of Lowry et al. (1951) using lysozyme as the standard.

The specific growth rate $(\mathrm{K})$ and $\log _{10}$ specific growth rate $\left(\log _{10} \mathrm{~K}\right)$ of $N$. commune growing at different temperatures $\left(5\right.$ to $\left.35^{\circ} \mathrm{C}\right)$ are shown in Table 1 . The optimum temperature $\left(\mathrm{T}_{\mathrm{opt}}\right)$ for growth of $N$. commune ranged in between 15 and $25^{\circ} \mathrm{C}$ with less difference in $\mu_{\max }$ values. The specific growth rate of $N$. commune was maximal at $25^{\circ} \mathrm{C}$. Maximum growth rate was 1.9590 day $^{-1}$ at $15{ }^{\circ} \mathrm{C}$. The $Q_{10}$ value ranged from $2-3$. Results suggest psychrotrophic behavior of $N$. commune.

Table 1. Effect of temperature on growth characteristics of $N$. commune.

\begin{tabular}{lll}
\hline Temperature $\left({ }^{\circ} \mathrm{C}\right)$ & $\boldsymbol{\mu}$ & $\log \mathbf{K}_{\mathbf{1 0}}$ \\
\hline 5 & 0.48 & 0.5972 \\
15 & 1.0072 & 1.9590 \\
25 & 1.48 & 1.2900 \\
35 & 0.48 & 0.4800 \\
\hline
\end{tabular}

Curve fitting results suggest that $N$. commune grew exponentially from 3 to 9 day at $25^{\circ} \mathrm{C}$, and 9 to 15 day at $5^{\circ} \mathrm{C}$ (Figure 1). After a downshift in temperature from 25 to $5{ }^{\circ} \mathrm{C}$, exponential phase of the cyanobacterium moved from 3 to 9 day. Duration of lag phase also increased following the downshift. The stationary growth phase started from $15^{\text {th }}$ day for cultures growing at $5{ }^{\circ} \mathrm{C}$, and continued with increase in incubation period. This indicates the adaptability of $N$. commune to low temperature $\left(5^{\circ} \mathrm{C}\right)$, and its preference for $25^{\circ} \mathrm{C}$. Maximum increase in biomass was recorded at $24^{\text {th }}$ day at $25^{\circ} \mathrm{C}$ and on $12^{\text {th }}$ day at $5^{\circ} \mathrm{C}$ (Figure 2).

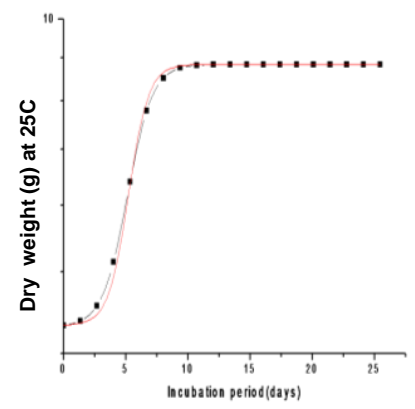

A

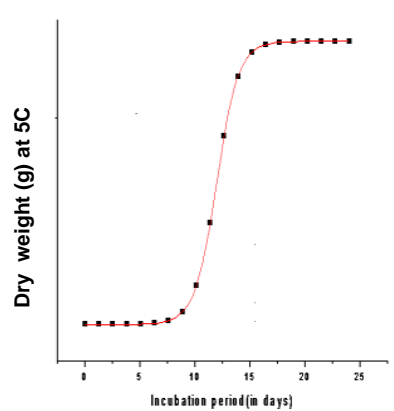

B
Figure 1. Best fit curve of Nostoc commune. A. at $25^{\circ} \mathrm{C}$, B. at $5{ }^{\circ} \mathrm{C}$.

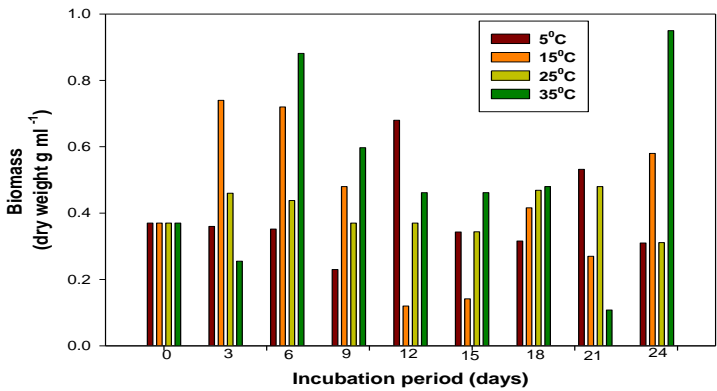

Figure 2. Biomass accumulation by $N$. commune at different temperatures $\left(5-35^{\circ} \mathrm{C}\right)$.

Maximum amount of chl $a$ was recorded on $27^{\text {th }}$ day for cultures growing at $25^{\circ} \mathrm{C}$. The downshift from 25 to $5^{\circ} \mathrm{C}$ had almost negligible effect on chl $a$ content. The chl $a$ content increased from 0.49 to $0.703 \mu \mathrm{g} \mathrm{mL} \mathrm{m}^{-1}$ at $35^{\circ} \mathrm{C}$ during first 6 days of incubation and remained constant thereafter (Figure 3). Maximal protein content was recorded for cultures growing at $5^{\circ} \mathrm{C}$ on $12^{\text {th }}$ day. Protein synthesis was exponential from 9 to 15 days (Figure 4).

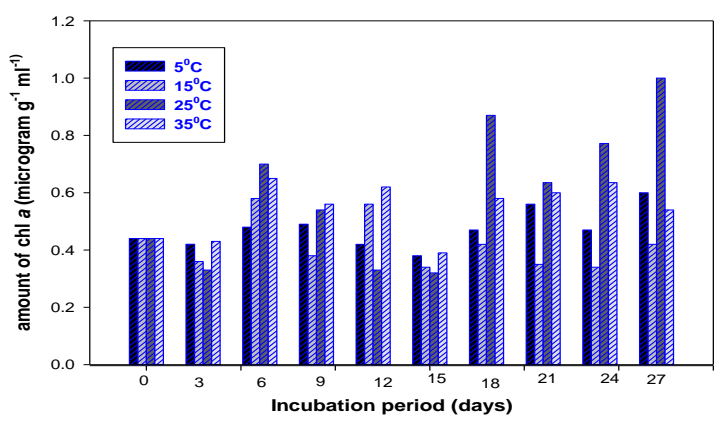

Figure 3. Effect of temperature $\left(5-35^{\circ} \mathrm{C}\right)$ on chl $a$ content of $N$. commune.

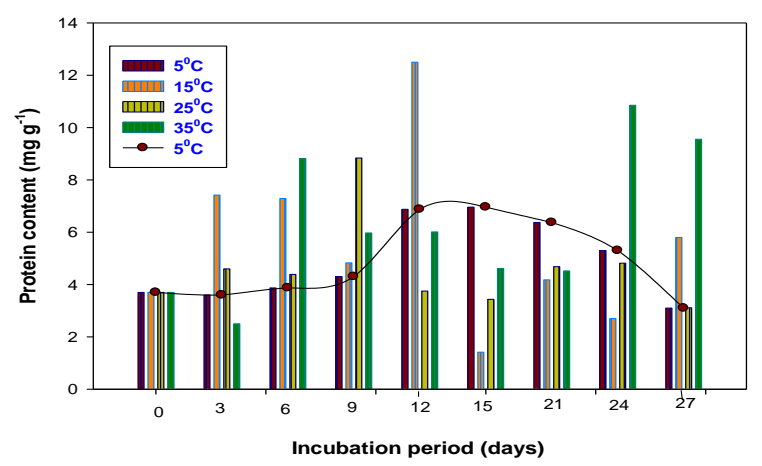

Figure 4. Effect of temperature $\left(5-35^{\circ} \mathrm{C}\right)$ on protein content of $N$. commune. 
$\mathrm{PC} / \mathrm{chl} a$ ratio was highest on $21^{\text {st }}$ day at $35^{\circ} \mathrm{C}$. At $5{ }^{\circ} \mathrm{C}$, the ratio of $\mathrm{PC} / \mathrm{chl} a$ increased upto $6^{\text {th }}$ day, decreased thereafter. A minimum increase in PC/chl $a$ ratio $(0.0148$ and 0.0126 ) was recorded on day $15^{\text {th }}$ (also 18 days) at 5 ${ }^{\circ} \mathrm{C}$. The maximum increase in $\mathrm{PC} / \mathrm{chl} a$ ratio $(0.1876)$ was recorded on 21 days at $25^{\circ} \mathrm{C}$ (Figure 5A). PE/chl $a$ ratio was maximum on $21^{\text {st }}$ day for cultures growing at $35^{\circ} \mathrm{C}$. However, cultures growing at 5 and $15^{\circ} \mathrm{C}$ exhibited minimum PE/chl $a$ ratio on $15^{\text {th }}$ and $18^{\text {th }}$ day, respectively. The ratio increased upto $12^{\text {th }}$ day at $5{ }^{\circ} \mathrm{C}$ and declined thereafter (Figure 5B). APC/chl a ratio was found to be highest on $24^{\text {th }}$ day at $15^{\circ} \mathrm{C}$. Its value for cultures growing at $5^{\circ} \mathrm{C}$ increased from $12^{\text {th }}$ day (Figure $5 \mathrm{C}$ ).

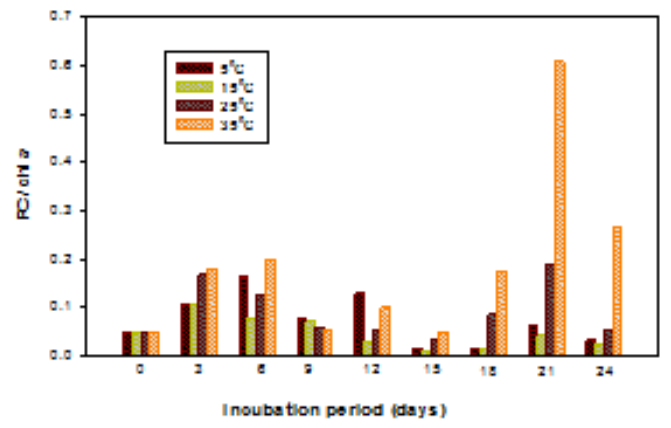

A
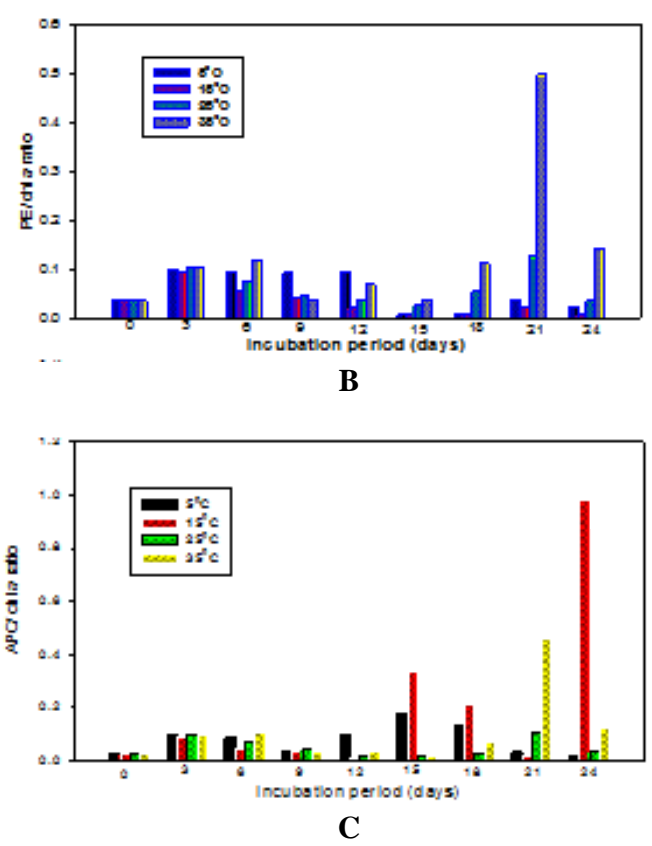

Figure 5. Effect of temperature on $N$. commune: A. PC/chl $a$ ratio, B. $\mathrm{PE} / \mathrm{chl} a$ ratio, $\mathrm{C}$. APC/chl $a$ ratio.

The carotenoids/chl $a$ ratio was maximum (2.48) on $9^{\text {th }}$ day at $5{ }^{\circ} \mathrm{C}$. It remained almost constant for cultures growing at 5 and $35{ }^{\circ} \mathrm{C}$ (Figure 6). Protein/chl $a$ ratio increased up to $24^{\text {th }}$ day at $5^{\circ} \mathrm{C}$. There was an induction in protein synthesis following downshift in temperature from 25 to $5^{\circ} \mathrm{C}$ (Figure 7 ).

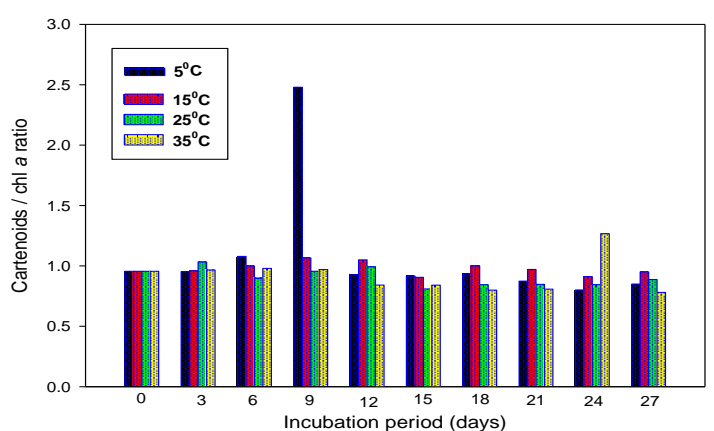

Figure 6. Effect of temperatures on carotenoids/chl $a$ ratio of $N$. commune.

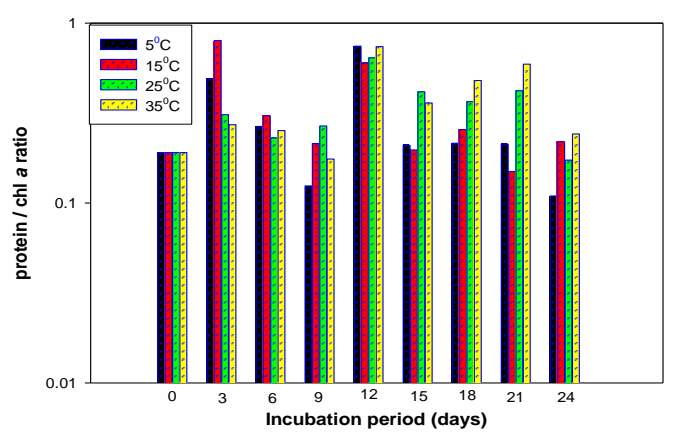

Figure 7. Effect of different temperature on protein/chl $a$ ratio of N. commune.

The growth and survival of cyanobacteria inhabiting Antarctic environments are less understood. N. commune grew within a range of $10-30{ }^{\circ} \mathrm{C}$, suggesting eurythermal (broad tolerance range) nature of the cyanobacterium. Reduced growth at low temperature (e.g. $\leq 5{ }^{\circ} \mathrm{C}$ ) and responsiveness to the temperature changes suggest that in Antarctica cyanobacteria could accumulate biomass during the brief periods of summer.

The increase in carotenoids/chl $a$ ratio at low temperature could help the cyanobacterium from protection against photooxidation, resulting in a low temperature (Young 1991; Chalifour and Juneau 2011). The consistent decrease in phycobiliproteins/chl $a$ ratio with increasing temperature suggests that all pigment ratios (including carotenoids/chl $a$ ) is controlled primarily by cellular chl $a$ content (biosynthesis).

The algal communities in the polar environments are exposed to continuous high irradiance during the summer. This, in combination with the low temperature, it increases the chances of photoinhibition (Bascuñán-Godoy et al. 2012). It was reported that carbon fixation limits growth and photosynthesis at low temperature, and algae tend to direct resources away from the synthesis of light-harvesting components at low temperature (Alves et al. 2002) 


\section{ACKNOWLEDGEMENTS}

We thank the Head, Department of Botany, Banaras Hindu University, Varanasi, UP, India for providing necessary facilities. This manuscript is dedicated to late Prof. S. N. Tripathi.

\section{REFERENCES}

Alves CA, Magalhães ACN, Barja PR. 2002. The Phenomenon of Photoinhibition of Photosynthesis and Its Importance in Reforestation. The Botanical Review 68(2): 193-208.

Bascuñán-Godoy L, Sanhueza C, Cuba M, Zuñiga GE, Corcuera LJ, Bravo LA. 2012. Cold-acclimation limits low temperature induced photoinhibition by promoting a higher photochemical quantum yield and a more effective PSII restoration in darkness in the Antarctic rather than the Andean ecotype of Colobanthus quitensis Kunt Bart (Caryophyllaceae). BMC Plant Biol 12:114.

Cavicchioli R, Siddiqui KS, Andrews D, Sowers KR. 2002. Low temperature extremophiles and their applications. Curr Op Biotechnol 13: $253-261$

Chalifour A, Juneau P. 2011. Temperature-dependent sensitivity of growth and photosynthesis of Scenedesmus obliquus, Navicula pelliculosa and two strains of Microcystis aeruginosa to the herbicide atrazine. Aqua Toxicol 103: 9-17.

Chattopadhyay MK. 2006. Mechanism of bacterial adaptation to low temperature. J Biosci 31 (1): 157-165.
Lowry OH, Rosebrough NJ, Farr AL, Randall RJ. 1951. Protein measurement with the folin-phenol reagent. J Biol Chem 193: 265275.

Morita RY. 1975. Psychrophilic bacteria. Bacteriol Rev 39: 144-167.

Myers J, Kratz WA. 1955. Relationship between pigment content and photosynthetic characteristics in blue-green algae. J Gen Physiol 39: 11-21.

Nadeau TL, Castenholz RW. 2000. Characterization of psychrophilic Oscillatorians (Cyanobacteria) from Antarctic meltwater ponds. J Phycol 36: 914-923.

Nadeau TL, Mibrandt EC, Castenholz RW. 2001. Evolutionary relationships of cultivated Antarctic Oscillatiorians (cyanobacteria). J Phycol 37: 353-360.

Pandey V, Upreti DK. 2000. Seventeenth Indian Expedition to Antarctica, Scientific Report. DOD, New Delhi.

Seaberg KG, Parked BC, Wharton RA, Simmons GM. 1981. Temperature-growth responses of algal isolates from Antarctic oases. J Phycol 17: 353-360.

Talling JF, Driver D. 1963. Some problems in the estimation of chlorophyll-A in phytoplankton. In Proceedings of the Conference on Primary Productivity Measurement, Marine and Freshwater, held at Honolulu in 1961. U.S. Atomic Energy Commission, Division of Technical Information TID-7633, Biology and Medicine, p. 142-146.

Tandeau de Marsac N, Houmard J. 1993. Adaptation of cyanobacteria to environmental stimuli: new steps towards molecular mechanisms. FEMS Microbiol Rev 104: 119-190.

Veerapaneni R. 2009. Analysis and characterization of microbes from ancient glacial ice. [Dissertation]. Graduate College of Bowling Green State University, India.

Young AJ. 1991. The photoprotective role of carotenoids in higher plants. Physiol. Plant 83: 702-708. 